\title{
ARE EXTERNAL TECHNOLOGY SOURCING STRATEGIES SUBSTITUTES OR COM PLEMENTS? \\ THE CASE OF EMBODIED VERSUS DISEMBODIED TECHNOLOGY ACQUISITION
}

\author{
Bruno Cassiman
}

Reinhilde Veugelers 
The Public-Private Center is a Research Center based at IESE Business School. Its mission is to develop research that analyses the relationships between the private and public sectors primarily in the following areas: regulation and competition, innovation, regional economy and industrial politics and health economics.

Research results are disseminated through publications, conferences and colloquia. These activities are aimed to foster cooperation between the private sector and public administrations, as well as the exchange of ideas and initiatives.

The sponsors of the SP-SP Center are the following:

- Accenture

- Ajuntament de Barcelona

- Official Chamber of Commerce, Industry and Navigation of Barcelona

- BBVA

- Diputació de Barcelona

- Garrigues, Abogados y Asesores Tributarios

- Catalan Government (Generalitat de Catalunya)

- Sanofi-Aventis

- Telefonica

- T-Systems

- VidaCaixa

The contents of this publication reflect the conclusions and findings of the individual authors, and not the opinions of the Center's sponsors. 


\title{
ARE EXTERNAL TECHNOLOGY SOURCING STRATEGIES SUBSTITUTES OR COM PLEMENTS? \\ THE CASE OF EMBODIED VERSUS DISEMBODIED TECHNOLOGY ACQUISITION
}

\author{
Bruno Cassiman* \\ Reinhilde Veugelers**
}

\begin{abstract}
This paper analyzes the choice between different external technology sourcing activities of a firm. On one hand, the firm can acquire new technology which is embodied in personnel. On the other hand, the firm can obtain new technology disembodied through a licensing agreement or by outsourcing the technology development from an R\&D contractor. Building on Cassiman and Veugelers (2006), we test whether embodied and disembodied technology acquisitions are complementary activities or rather behave as substitute technology acquisition alternatives. We find that while internal and external technology acquisition are complementary innovation activities, the actual choice of external technology sourcing between embodied or disembodied modes is substitutive for smaller firms. The evidence for larger firms suggests that different external technology sourcing activities are complementary, but in this case the results are suggestive although not strongly significant.
\end{abstract}

* Professor, General Management, IESE, Katholieke Universiteit Leuven and CEPR

** European Commission (BEPA), Katholieke Universiteit Leuven and CEPR

Keywords: Embodied and Disembodied Technology acquisition, complementarity, substitutability. 


\section{ARE EXTERNAL TECHNOLOGY SOURCING STRATEGIES SUBSTITUTES OR COM PLEMENTS? THE CASE OF EMBODIED VERSUS DISEMBODIED TECHNOLOGY ACQUISITION*}

\section{Introduction}

Today, even the largest and most technologically self-sufficient organizations require knowledge from beyond their boundaries. In addition to doing own research and development, firms typically tap knowledge sources external to the firm by various means such as licensing, contracting out R\&D, acquisitions of other firms and attracting qualified researchers embodying relevant knowledge (A rora and Gambardella, 1994; Cockburn and Henderson, 1998; Granstrand et al., 1992). Furthermore, they can cooperate actively in R\&D with other firms and research organizations and/or attempt to absorb existing technology without any explicit involvement or permission from the innovator.

While most of the theoretical literature has focused on the choice between different innovation activities as substitutes, particularly the technology make and buy decision, the joint occurrence of these innovation activities at the firm level is suggestive of complementarity between these activities. A growing empirical literature has documented the complementarity between technology make and buy (Cassiman and Veugelers, 2006; Belderbos et al., 2004; A rora and Gambardella, 1994). Own internal know-how will increase the marginal return to external knowledge acquisition strategies. This is reminiscent of the notion of 'absorptive capacity' introduced by Cohen and Levinthal (1989), stressing the importance of a stock of prior knowledge to effectively scan, screen and absorb external know-how. At the same time, the access to external know-how may leverage the efficiency of internal R\&D activities.

Relatively few studies have focused on other parts of the innovation strategy. Belderbos et al. (2004) examine the substitute versus complementary relationship between various types of cooperative agreements. Arora and Gambardella (1990) examine complementarity among four different external sourcing strategies of large chemical and pharmaceutical firms in biotechnology (agreements with other firms, with universities, investments in NTBFs and acquisitions of NTBFs). They find evidence for the joint occurrence of all types of external sourcing strategies, even after correcting for a set of firm characteristics.

\footnotetext{
* Both authors acknowledge support from the Flemish Government (SOOS), the first author from the Spanish Ministry of Education (SEJ 2006-11833/ECON), the second author from DWTC (IUAP P5/11/33) and KULeuven (OT/04/07A). Bruno Cassiman is a fellow of the SPSP Research Center at IESE Business School.
} 
In this study, we take a closer look at the relationship between various external technology acquisition strategies for a set of innovative companies across all manufacturing sectors, drawn from the Community Innovation Survey for Belgium. We distinguish two broad types of external technology sourcing decisions by the firm. On one hand, the firm can acquire new technology which is embodied in new personnel that is attracted to it. On the other hand, the firm can obtain new technology disembodied through a licensing agreement or by outsourcing the technology development from an R\&D contractor. Using the methodology developed in Cassiman and Veugelers (2006), we systematically examine the substitute versus complementary relationship between these two different types of technology acquisition. Going beyond the mere identification of the relationship, the analysis also focuses on the contextual variables affecting this perceived relationship. We find that while internal and external technology acquisitions are complementary, the actual choice of external acquisition between embodied or disembodied modes is substitutive for smaller firms. Larger firms tend to combine these different external technology sourcing strategies, but complementarity effects are not significant.

The next section reviews the literature on technology buy decisions. Section 3 describes our sample and section 4 presents the results on who buys technology and how they organize these transactions. Section 5 concludes.

\section{Technology Buy: Theory}

The existing literature on the decision to buy technologies is mostly focused on the "make versus buy" decision. Less theory exists on comparing different modes of acquiring technology. This section reviews the economic theory on technology buy and scans the technology management literature on advantages and disadvantages of the various modes of technology acquisition.

In the economics literature, technology acquisition is typically of the disembodied kind, through licensing (in case of "off the shelf" technologies) or R\&D contracting (if the know-how still needs to be developed). Building further on the general literature on make or buy decisions, i.e. transaction cost economics (Williamson, 1985) and property rights theory (Grossman and Hart, 1986), the theoretical framework for explaining disembodied acquisition stresses the advantage of tapping existing, often more specialized knowledge, if available. This leads to time gains and lower innovation costs, at least if the market for disembodied technologies is sufficiently developed. However, disembodied acquisition may create considerable transaction costs, ex ante in terms of search and negotiation costs and ex post to enforce contracts. The typical uncertain nature of $R \& D$ projects exacerbates these transaction costs. Hence, disembodied acquisition is more likely to occur for generic, non-firm specific, already sufficiently standardized know-how (Mowery and Rosenberg, 1989).

Beyond disembodied technology acquisition, external know-how can also be accessed, without any explicit involvement from the sending party (Arrow, 1962). The channels through which such "spillovers" occur are many, ranging from informal communications networks, meetings, input suppliers and customers, patent applications, reverse engineering, and mobility of researchers. ${ }^{1}$ An extensive theoretical literature in Industrial Organization has developed around the effects of such spillovers on the incentives for investment in R\&D, shedding further light on the relationship between technology buy and make. Whether spillovers and own R\&D will act

\footnotetext{
${ }^{1}$ Gersbach and Schmutzler (2003) develop a model for endogenizing spillovers through the labor market for R\&D employees.
} 
as substitutes or complements depends on the competition regime, the need for absorptive capacity and the strength of the appropriability regime (see De Bondt, 1997, for a review).

The technology management literature further clarifies the drivers of the choice between technology buy and make. It emphasizes as advantages of external sourcing the option to get quick access to technological know-how, which is important when the firm lacks familiarity with, or competence in, the new market/technology. At the same time, this already indicates a major roadblock to external sourcing, namely, matching the existing technological capabilities of the receiving firm with the transmission capacity of the source. Chatterji (1996) pinpoints as a general problem in external sourcing strategies an insufficient "post-agreement" management and commitment to the external sourcing strategy. To overcome the extra costs of external sourcing, an organizational structure that builds in absorptive capacity and is able to overcome the classic "not invented here" syndrome is an important asset. Allen (1977) suggests the use of technological gatekeepers to improve the external sourcing strategy, as a way of bridging the gap between internal and external environment.

Beyond the choice between make and buy, the technology management literature also discusses the choice among the various external sourcing modes. When choosing the mode of external sourcing, ranging from acquisition to majority-minority holdings to networking and short-term contracting, firms have to trade off commitment and control versus flexibility (Roberts and Berry, 1985). More flexible modes are more attractive for ill-defined, embryonic technology with a high level of risk and with which the company is unfamiliar, while higher control/ownership modes are more important when appropriation is weak, assets are specialized and the technology is highly relevant for sustaining a competitive advantage.

In addition, the appropriability regime will influence the selection of the external innovation activity (Teece, 1986). When appropriability is high, firms are willing to sell their technology to other firms to appropriate the benefits from innovating. Hence, firms that decide to acquire technology externally, will find it easier to acquire this technology in disembodied form such as through licensing agreements or R\&D contracts. Loose appropriation environments quickly erode a firm's technological advantage. In that case, firms will develop specialized complementary assets internally to protect their technology. This is reminiscent of the "resource-based" view of the firm that stresses the imperfect mobility of resources as a condition for sustaining a firm's competitive advantage. Firms that decide to acquire technology externally in this environment, acquire this technology in embodied form through the acquisition of other firms or by attracting specialized personnel.

To summarize, most of the existing literature, both economics and management, discusses external sourcing motives individually or in relationship with internal sourcing. If a relationship is suggested, it is mostly in the form of substitute choices for acquiring knowledge. However, instead of discussing "make or buy" or buying modes as substitutes, the potential for combining sourcing modes as complementary innovation strategies should not be ignored. Although one strategy may substitute for the other at the project level, combining sourcing creates extensive scope for complementarities, particularly at the firm level, across projects. If combining different sourcing strategies increases the efficiency of each sourcing strategy, they are more likely to be observed in combination. But which conditions need to be present to realize the scope for complementarity? Arora and Gambardella (1994) identify internal knowledge capabilities which allow effective use of foreign know-how, stimulating external sourcing. Internal capabilities generate an ability to better screen available external projects. Once developed within the firm, this capacity will lead to a more focused search, which may 
reduce or stimulate various external sourcing activities. In any case, internal capabilities are needed to lead and support the external sourcing effort. Cassiman and Veugelers (2006) identify the reliance on basic R\&D - as measured by the importance of universities and research centers as an information source for the innovation process - as an important contextual variable affecting complementarity between internal and external innovation activities. In a similar spirit, firms which have developed basic R\&D capabilities may be more prolific in developing several external sourcing strategies simultaneously.

Large firms can be expected to be less likely to buy on a larger scope and scale, to the extent that scale advantages in R\&D can be realized in-house. To the extent that large firms have own in-house R\&D with better absorptive capacities, they are better tuned to benefit from external sourcing (see Arora and Gambardella, 1990; Gambardella, 1992; and Cockbur and Henderson, 1998 for evidence on this from the pharmaceuticals industry). The specific problems of SMEs in establishing external linkages are tackled in Rothwell and Dodgson (1991). These authors again stress that a SME's ability to access external know-how is conditioned by its in-house employment of qualified technical specialists, scientists and engineers.

\section{Measuring Complementarity (Supermodularity) or Substitutability (submodularity)}

\subsection{A framework for assessing complementarity/substitutability}

The notion of fit or complementarities between activities thrives in the management literature, but often as an ill-defined concept. Following Cassiman and Veugelers (2006), we define complementarity explicitly building further on the theory of supermodularity (see Milgrom and Roberts, 1990 and 1995). This elegant mathematical theory states the necessary conditions for activities to be complementary.

Suppose there are 2 activities $A_{1}$ and $A_{2}$, each activity can be done by the firm $\left(A_{i}=1\right)$ or not $\left(A_{i}=0\right)$ and $i \in\{1,2\}$. The function $\Pi\left(A_{1}, A_{2}\right)$ is supermodular and $A_{1}$ and $A_{2}$ are complements only if:

$$
\Pi(1,1)-\Pi(0,1) \geq \Pi(1,0)-\Pi(0,0),
$$

i.e. adding an activity while already performing the other activity has a higher incremental effect on performance (П) than when doing the activity in isolation.

Furthermore, the same mathematical theory defines submodularity and substitutability when the sign is reversed, i.e.

The function $\Pi\left(A_{1}, A_{2}\right)$ is submodular and $A_{1}$ and $A_{2}$ are substitutes only if:

$$
\Pi(1,1)-\Pi(0,1) \leq \Pi(1,0)-\Pi(0,0),
$$

i.e. adding an activity while already performing the other activity has a lower incremental effect on performance $(\Pi)$ than when doing the activity in isolation.

Two interesting empirical predictions follow from this theory (See Arora, 1996; A they and Stern, 1998). Two activities that are complementary will be positively correlated, while negative correlation is consistent with substitutes. Correlation, however, is neither necessary nor sufficient if the conditions specified supra do not hold, particularly if there are more than two activities to decide on (Arora, 1996). The main problem is that unobserved heterogeneity between different observations could bias the estimation results and can lead both to accepting 
the complementarity (substitutability) hypothesis when none exists, or to rejecting the complementarity (substitutability) hypothesis when activities in fact are complementary (substitutes) (see Athey and Stern, 1998).

The second result is the use of exclusion restrictions to assess the existence of complementarity (substitutes). Suppose that two different activities are complementary (substitute). Suppose further that there is an exogenous variable in the environment only affecting the likelihood of observing one activity. Then, in addition to the positive direct effect of this variable on the choice of this one activity, we should also find a positive (negative) indirect effect on the other activity, because of the complementarity (substitution) between the two activities.

\subsection{Measuring complementarity/substitutability among external sourcing modes}

In order to test for the relation between different external sourcing activities of the firm, two different approaches present themselves: the productivity and the adoption approach. In the productivity approach, the nature of the relation is tested directly by regressing a measure of performance of the innovation process on exclusive combinations of our external sourcing activities. In particular, we create a dummy variable that indicates whether the firm acquired technology disembodied through licensing or R\&D contracting (DEMB) or embodied by acquiring specialized personnel (EMB) - the firm's external sourcing activities. From these dummy variables we construct different exclusive categories - the firm's external sourcing strategy: firms that have no external sourcing (NODEMB\&EMB); firms that only buy disembodied (DEMBOnly); firms that only acquire technology embodied through personnel (EMBOnly); and firms that combine embodied and disembodied technology acquisition (DEM B\&EM B).

The innovation performance measure used is the percentage of sales that is generated from new or substantially improved products introduced in the past two years $\left[\Pi\left(A_{1}, A_{2}\right)\right]$. By restricting the performance measure to innovation performance only, rather than overall firm performance, we attempt to reduce the problem of having to correct for other sources of firm heterogeneity that influence overall performance. Furthermore, innovation performance has been linked to overall firm performance (o.a. Crépon et al., 1998). The test for complementarity (substitutability) between two innovation activities, $A_{1}$ and $A_{2}$, is:

$$
\theta_{11}-\theta_{10} \geq(\leq) \theta_{01}-\theta_{00}
$$

with $\theta_{k l}$ the coefficients on the innovation strategy choice of the firm. The proposed test follows directly from the theoretical development of complementarity/substitutability and establishes the existence of complementarity/substitutability conditional on having unbiased estimates for the $\theta$-coefficients. A maintained assumption for this analysis to provide unbiased estimates is that the drivers of adoption decisions, $A_{1}$ and $A_{2}$, are uncorrelated with the error term $\varepsilon^{2} .^{2}$

In the adoption approach, we test the nature of the relation between innovation activities through an exclusion restriction on a bivariate probit model. The bivariate probit regresses the non-exclusive innovation activities (DEM B and EMB) on assumed exogenous control variables ( $\left.Z^{i}\right)$ but explicitly takes into account the correlation between them. We are particularly

\footnotetext{
${ }^{2}$ See Cassiman and Veugelers (2006) for an extensive discussion about this methodology and its underlying assumptions.
} 
interested in variables that are expected to affect exclusively only one of the innovation activities, but still appear significantly in the other innovation activity, too.

We also want to assess the factors affecting complementarity or substitutability of the external innovation activities. We estimate a multinomial logit model examining the drivers for the combinations of innovation activities (in casu: NoEMB\&DEMB; DEMBOnly; EMBOnly; $D E M B \& E M B)$. The multinomial logit model reveals drivers of exclusive combinations of the different external sourcing strategies. For a complementary relation we are interested in the drivers that affect the joint adoption of external sourcing activities, i.e. variables that show up significantly in the multinomial logit results for DEMB\&EMB, while not being significant for other external sourcing strategy choices. For a substitute relation, we are interested in the drivers that affect the exclusive categories, i.e. variables that show up significantly in the multinomial logit results for DEMBOnly and/or EMBOnly while not being significant for other external sourcing strategy choices.

To summarize, our empirical strategy for evaluating complementarity or substitutability in the external sourcing strategy follows three steps. First, we directly test for the nature of the relationship (complementarity/substitutability) as described in the productivity approach. Second, in an effort to understand the variables that affect the choice of different external sourcing strategies, we perform the multinomial logit. This analysis reveals different drivers of external sourcing activities and hints towards contextual variables affecting the joint adoption of external sourcing activities versus the exclusive adoption of such activities. In a third step, we use this latter information to refine our analysis for evaluating complementarity or substitutability by estimating a bivariate probit model using the drivers of innovation strategies that have been uncovered and testing a possible exclusion restriction.

\section{Sample}

The data used for this research are innovation data on the Belgian manufacturing industry that were collected as part of the Community Innovation Survey conducted by Eurostat in the different member countries in 1993. A representative sample of 1335 Belgian manufacturing firms was selected resulting in a response of 735 usable questionnaires. About $60 \%$ of the firms in the sample claim to innovate, while only $40 \%$ do not innovate. For the remainder of our analysis, we restrict attention to the innovation-active firms in the sample that performed internal R\&D in $1992^{3}$. Innovation-active firms are distinguished by their answer on the question whether they were actively engaged in introducing new or improved products or processes in the last two years. Our effective sample without missing values consists of 215 observations.

For this sample we can identify whether and how firms acquire new technology. Identification of external sourcing is based only on whether one of these external sourcing activities has been used or not. The CIS survey identifies several types of technology acquisition. First, the organization can acquire new technology that has to be assimilated by the organization. Disembodied technology acquisition strategies include licensing, R\&D contracting and the use of technology consulting agencies. Second, new technology can be acquired that is embodied in the good or asset that is acquired: embodied technology acquisition. Such strategies include

\footnotetext{
${ }^{3}$ The sample of observations that contain information on external acquisition is restricted to innovation-active firms. Within this sample, almost all firms were simultaneously engaged in internal R\&D.
} 
acquisition of firms (take-overs), attracting qualified personnel and the purchase of equipment. Not included in the main analysis is the disembodied purchase of consulting services, the embodied purchase of equipment and the acquisition of other firms; the former two because probably not all of firms interpreted the question as buying with the explicit purpose of obtaining new technologies; ${ }^{4}$ the latter because it is a very specific and too infrequently chosen activity in our sample. ${ }^{5}$ This ultimately leaves us with DEMB acquisition through licensing and/or R\&D contracting on one hand ${ }^{6}$ and EMB acquisition through acquisition of skilled workers on the other hand.

Table 1 summarizes the information about the firm's external sourcing activities. Almost three quarters of the innovating firms acquire technology on the external market using at least one of the two possible external sourcing activities. Embodied and disembodied technology acquisitions are slightly positively correlated (correlation coefficient of 0.07 ). ${ }^{7}$ The positive correlation between the different external knowledge acquisition activities confirms the results from Arora and Gambardella (1990) in biotechnology.

\footnotetext{
${ }^{4}$ In addition, buying equipment from suppliers is clearly a different strategy, as noted by Pavitt (1984), who found that supplier-dominated industries are less $R \& D$-intense and more process-oriented than other industries.

5 Reported results are not sensitive for including in the EMB also acquisition of firms and in the DEMB also consulting.

${ }^{6}$ As reported infra, licensing and R\&D contracting are highly positively correlated, which is why we have grouped them together in DEMB. Only including either licensing or R\&D contracting individually as DEMB acquisition did not yield significantly different results from those reported here.

${ }^{7}$ Licensing and R\&D Contracting have a correlation of about 0.29 ( 0.22 for firms with less than 250 employees; 0.29 for firms with more than 250 employees) which is much higher than across embodied and disembodied acquisition strategies.
} 


\section{Table 1}

Frequency of External Technology Sourcing Activities and Pairwise correlation

\begin{tabular}{|c|c|c|c|c|c|c|c|}
\hline $\begin{array}{l}\text { Innovation } \\
\text { Activity }\end{array}$ & Variable Construction & $\begin{array}{c}\text { Number of Firms } \\
\text { without missing } \\
\text { values } \\
\mathrm{N}=215 \\
\end{array}$ & $\begin{array}{c}\text { Firms with less } \\
\text { than } \\
250 \text { employees } \\
N=106 \\
\end{array}$ & $\begin{array}{c}\text { Firms with more } \\
\text { than } \\
250 \text { employees } \\
N=109\end{array}$ & & & \\
\hline$B U Y$ & $\begin{array}{l}\text { Innovative firms acquiring } \\
\text { technology through at least one of } \\
\text { the following external technology } \\
\text { acquisition modes: Licensing } \\
\text { and/or R\&D Contracting and/or } \\
\text { Hire-away }(0 / 1) \text {. }\end{array}$ & $156(73 \%)$ & 73 (69\%) & $83(76 \%)$ & \multirow{3}{*}{\multicolumn{3}{|c|}{$\begin{array}{c}\text { Pairwise Correlation (DEMB, } \\
\text { EMB) }\end{array}$}} \\
\hline Licensing & $\begin{array}{l}\text { Innovative firms acquiring } \\
\text { technology through licensing }(0 / 1)\end{array}$ & $73(34 \%)$ & $24(23 \%)$ & $49(45 \%)$ & & & \\
\hline $\begin{array}{r}R \& D \\
\text { Contracting }\end{array}$ & $\begin{array}{l}\text { Innovative firms acquiring } \\
\text { technology through } R \& D \\
\text { contracting. }\end{array}$ & $89(41 \%)$ & $33(31 \%)$ & $56(51 \%)$ & & & \\
\hline DEMB & $\begin{array}{l}\text { Innovative firms acquiring } \\
\text { technology through licensing }(0 / 1) \\
\text { and/or } R \& D \text { contracting. }\end{array}$ & 117 (54\%) & $45(42 \%)$ & $72(66 \%)$ & Total & $<250$ & $>250$ \\
\hline$E M B$ & $\begin{array}{l}\text { Innovative firms acquiring } \\
\text { technology through hiring away } \\
\text { personnel. }\end{array}$ & $94(44 \%)$ & $48(45 \%)$ & $46(42 \%)$ & 0.07 & -0.02 & 0.18 \\
\hline
\end{tabular}

In the sample of innovative companies, about half of the firms have less than 250 employees. These small firms in particular are less likely to buy disembodied technology, i.e. R\&D contracting and licensing. For these small firms, embodied and disembodied technology acquisition is actually (marginally) negatively correlated, while for large firms these external sourcing activities are positively correlated (correlation coefficient of 0.18 ).

Table 2 analyses the frequency and performance of the exclusive external knowledge acquisition strategies. In the total sample, the absence of an external sourcing strategy (NoDEM B \&EM B) clearly underperforms in terms of innovative output. The combination of both embodied and disembodied acquisition (DEMB\&EMB) clearly improves on innovative performance, but the best performing external sourcing strategy seems to be the embodied acquisition only (EMBonly). This result is mainly driven by the small firms in the sample. Small firms (less than 250 employees) are significantly more likely to buy embodied knowledge only. The combination of external sourcing activities is much less likely for these firms. The EMBonly acquisition strategy also significantly outperforms the other activity combinations for the small firms when measuring the percentage of sales coming from new products. For large firms (more than 250 employees), a combination strategy works best. These first results seem to suggest that small firms face a substitute relation between external sourcing activities, while larger firms on the contrary might find these activities to be complementary within their innovation process. To confirm these findings, we need to explicitly test the relation. 


\section{Table 2}

Frequency of External Technology Sourcing Strategies and Innovation Performance by Strategy

\begin{tabular}{|l|c|c|c|c|c|c|}
\hline & \multicolumn{2}{|l|}{ Total Sample } & \multicolumn{2}{l|}{ Size $\leq 250$} & \multicolumn{2}{l|}{ Size >250 } \\
\hline & Frequency & $\begin{array}{l}\text { \% Sales from } \\
\text { New Products }\end{array}$ & Frequency & $\begin{array}{l}\text { \% Sales from } \\
\text { New Products }\end{array}$ & Frequency & $\begin{array}{l}\text { \% Sales from } \\
\text { New Products }\end{array}$ \\
\hline NoDEMB\&EMP & 59 & 13.25 & $33(31 \%)$ & 15.8 & $26(24 \%)$ & 10.0 \\
\hline DEMB Only & 62 & 17.4 & $25(24 \%)$ & 16.9 & $37(34 \%)$ & 17.7 \\
\hline EMB Only & 39 & 23.3 & $28(26 \%)$ & 25.8 & $11(10 \%)$ & 17.0 \\
\hline DEMB\&EMB & 55 & 20.0 & $20(19 \%)$ & 16.5 & $35(32 \%)$ & 22.0 \\
\hline Total & 215 & & 106 & & 109 & \\
\hline
\end{tabular}

\section{Econometric results on who buys how?}

Our methodology to examine the substitute versus complementary relationship between embodied and disembodied technology acquisition consists of three steps. First, we directly test for complementarity/substitutability in the productivity analysis. Second, we perform the multinomial logit in search of the variables that affect the choice between different external sourcing strategies. In a third step, we estimate a bivariate probit model using the drivers of external sourcing strategies that have been uncovered and test a possible exclusion restriction.

\subsection{The variables and hypotheses}

Productivity analysis: the drivers of innovative performance

First we analyze how combining external sourcing activities affects the performance of the innovation process. We regress our measure of innovation performance (\% Sales from New Products) on the exclusive combinations of external sourcing activities, together with firm characteristics and industry dummies that may affect the performance of the innovation process. Table 3 presents the definitions of these variables.

Since Schumpeter's work, the size of the firm has traditionally been an important control variable (see, among others, Cohen and Levin, 1989). On the one hand, larger firms may have higher market power or may enjoy economies of scale and scope, raising the profitability of an innovation strategy. On the other hand, smaller firms are associated with less bureaucracy and so may be more innovation efficient (Acs and Audretsch, 1987). Or smaller innovative firms may just have it easier than large firms when it comes to increasing sales of new or substantially improved products as a percentage of their total sales. We measure size by the natural logarithm of the number of employees of the firm in 1992 (Size). In addition, we control for the inputs into innovation activities, i.e. innovation expenditures relative to sales. The questionnaire asked for the amount (in Belgian francs) spent on all innovation activities, including own R\&D, licensing and R\&D contracting, and other development activities. Innovation-intensive firms are likely to produce more innovations, thus making sales of new products a larger percentage of total sales (Innovation Intensity). Given that the profitability of an innovation strategy is likely to be affected by the competitiveness of the environment and 
that exporting firms tend to encounter a more competitive environment, a firm's export intensity (Export Intensity), i.e. the percentage of 1992 sales generated from exports, should positively affect innovation performance. Last of the generic firm-specific control variables are lack of technological opportunity (Technology Obstacles) and lack of market opportunities (Market Obstacles), as perceived by the firm. These exogenous factors capture, respectively, supply factors and demand factors affecting the scope for innovative performance. Both types of obstacles are expected to reduce innovation performance. In addition, we include industry dummies at the two-digit industry classification level.

\section{Table 3}

Variable Definitions

\begin{tabular}{|c|c|c|}
\hline \multicolumn{2}{|c|}{ Variable Name } & Variable Construction \\
\hline \multicolumn{2}{|c|}{$\begin{array}{l}\text { \% Sales from New Products } \\
\text { (dependent variable) }\end{array}$} & $\begin{array}{l}\text { Percentage of total sales derived from new or substantially } \\
\text { improved products introduced between } 1990 \text { and } 1992 .\end{array}$ \\
\hline \multicolumn{2}{|l|}{ Employment } & Natural Logarithm of Number of Employees of the firm in 1992. \\
\hline \multicolumn{2}{|c|}{ Innovation Intensity } & Expenditure on innovation activities relative to Sales. \\
\hline \multicolumn{2}{|c|}{ Export Intensity } & Export Intensity in 1992 (Exports/Sales x 0.1). \\
\hline \multicolumn{2}{|c|}{ Market Obstacles } & $\begin{array}{l}\text { Average measure of importance of lack of market information, } \\
\text { no need for innovation because of previous innovations, } \\
\text { problems with regulations, little interest in new products by } \\
\text { customers, uncertainty about market timing, as a barrier to } \\
\text { innovation (on scale } 1 \text {, unimportant, to } 5 \text {, crucial). }\end{array}$ \\
\hline \multicolumn{2}{|c|}{ Technological Obstacles } & $\begin{array}{l}\text { Importance of lack of technological opportunities as barrier to } \\
\text { innovation (on scale } 1 \text {, unimportant, to } 5 \text {, crucial). }\end{array}$ \\
\hline \multicolumn{2}{|c|}{ Effectiveness of IP Protection } & $\begin{array}{l}\text { Measure of effectiveness of patents as a means for protecting } \\
\text { innovation (firm-level measure on scale } 1 \text {, unimportant, to } 5 \text {, } \\
\text { crucial). }\end{array}$ \\
\hline \multicolumn{2}{|c|}{ Effectiveness of Strategic Protection } & $\begin{array}{l}\text { Average measure of effectiveness of secrecy, complexity and/or } \\
\text { lead time as a means for protecting innovation (on scale } 1 \text {, } \\
\text { unimportant, to } 5 \text {, crucial). }\end{array}$ \\
\hline \multicolumn{2}{|c|}{ Basic R\&D Reliance } & $\begin{array}{l}\text { Measure of importance for the innovation process of information } \\
\text { from research institutes and universities relative to the } \\
\text { importance of suppliers and customers as an information } \\
\text { source. }\end{array}$ \\
\hline \multicolumn{2}{|c|}{ Resource Limitations } & $\begin{array}{l}\text { Importance of lack of innovation and technical personnel as a } \\
\text { barrier to innovation (on scale } 1 \text {, unimportant, to } 5 \text {, crucial). }\end{array}$ \\
\hline \multicolumn{2}{|c|}{ Financial Limitations } & $\begin{array}{l}\text { Sum of scores of importance of following obstacles to innovation } \\
\text { process (number between } 1 \text {, unimportant, and } 5 \text {, crucial): (1) No } \\
\text { suitable financing available, (2) High costs of innovation, (3) } \\
\text { Pay-back period too long, (4) Innovation cost hard to control. } \\
\text { (rescaled between } 0 \text { and 1). }\end{array}$ \\
\hline \multicolumn{2}{|c|}{ IndEMB and IndDEMB } & $\begin{array}{l}\text { Average industry level of EMB/DEMB technology sourcing in 2- } \\
\text { digit NACE* industry. }\end{array}$ \\
\hline $\begin{array}{l}\text { INDUSTRY } \\
\text { DUMMIES }\end{array}$ & \multicolumn{2}{|c|}{$\begin{array}{l}\text { Industry dummies are included where the industry is defined as groupings of NACE2* digit } \\
\text { level industries: Steel (Nace } 22,9 \text { obs), Minerals (Nace } 24,11 \text { obs), Chemicals (Nace } 25 \\
\text { and } 26 \text { excluding } 2571 / 2572,30 \text { obs), Pharmaceuticals (Nace } 2571 / 2572,6 \text { obs), Metals } \\
\& \text { Metal products (Nace } 31,29 \text { obs), Electronics (Nace } 33 \text { and } 34 \text { ), Transport Equipment } \\
\text { (Nace } 35 \text { and } 36,13 \text { obs), Machinery\& Instruments (Nace } 32,37,29 \text { obs), } \\
\text { Food\&Beverages (Nace } 41 \text { and } 42,28 \text { obs), Textiles (Nace } 43,44 \text { and } 45,32 \text { obs), } \\
\text { Wood/Paper (Nace } 46 \text { and } 47,31 \text { obs), Rubber (Nace } 48,13 \text { obs), Other (Nace } 49,11 \\
\text { obs). }\end{array}$} \\
\hline $\begin{array}{l}\text { HIGH TECH } \\
\text { INDUSTRIES }\end{array}$ & \multicolumn{2}{|c|}{ High Tech industry dummy includes NACE2* industries as defined by OECD. } \\
\hline \multicolumn{3}{|c|}{$\begin{array}{l}\text { A total of } 714 \text { firms responded, } 445 \text { firms innovated in the full sample, } 215 \text { firms without missing values. } \\
\text { *NACE2: Statistical Classification of Economic Activities in the European Community at two digit level } \\
\text { (Nomenclature Statistique des Activités économiques dans la Communauté Européenne) }\end{array}$} \\
\hline
\end{tabular}


Adoption analysis: the drivers of external technology sourcing strategies

Next we examine the external sourcing strategy adoption decisions, either in a multinomial logit analysis (for the exclusive technology sourcing choices) or in the bivariate probit analysis (for the choice of embodied versus disembodied acquisition). There exists very little theory to formulate hypotheses on the variables that influence the firm's decision to opt for different modes of technology acquisition and in particular whether this acquisition happens in an embodied and/or disembodied form. Since we have no strong a priori expectations on the likely effects, the results reported should therefore be considered indicative of important relations between the mode of technology acquisition and firm and industry characteristics, and, are intended to stimulate further research on the issue.

Cassiman and Veugelers (2006) a.0. show that firms with basic R\&D capabilities are more likely to be engaged in combining own R\&D activities and external acquisition activities, as their higher absorptive capacity will increase the marginal returns from own R\&D in the presence of external acquisition, and vice versa. Their variable, Basic R\&D Reliance, measures the importance, for the innovation process, of information from research institutes and universities relative to the importance of suppliers and customers as an information source for the innovation process (see Table 3). We use this variable to proxy for the firm's reliance on more "basic" types of know-how and expect that, following Arora and Gambardella (1990), it might affect the marginal returns to all of the external sourcing activities as well.

Larger firms develop more projects and can benefit from economies of scale and scope in R\&D. They are therefore more likely to engage in innovation activities in general (Size). Furthermore, higher innovation expenditure, while controlling for size, also increases the likelihood of engaging in different innovation activities in general (Innovation Intensity). We also test whether obstacles to innovations such as a lack of innovation and technical personnel (Resource Limitations) or lack of financial resources (Financial Limitations) influence the firm's decision about the organization of its innovation strategy. A lack of internal resources may drive the firm towards external sourcing in general. Finally, when information from competitors (Competitor Information) is important, the firm is more likely to be either a follower or an imitator with respect to innovation. Therefore, firms in the same industry are more likely to catch up by accessing relevant state- of-the-art technology on the external technology market, positively affecting the external knowledge acquisition decision. It is not clear a priori how each of these variables is affecting the choice of external sourcing strategies in general, or whether they particularly favor an embodied and/or a disembodied choice.

The appropriation regime has been identified, in the theoretical literature, as an important factor affecting the (relative) importance of (different) innovation activities for a firm (Teece, 1986; Veugelers and Cassiman, 1999). If firms are able to appropriate the benefits from innovation, they have more incentives to invest in innovative strategies. This will apply for internal as well as external sourcing modes. But in addition, the nature of the appropriation mechanisms might matter. If firms rate legal protection of innovations through patents as effective, they may be more inclined to buy technology disembodied. Therefore, the effect of Effectiveness of IP Protection is expected to have a positive effect, particularly on the DEMB decisions. If innovations are easier to protect through strategic measures, such as secrecy, lead time or product or process complexity (Effectiveness of Strategic Protection), firms may favor own R\&D activities and embodied technology acquisitions, avoiding being active on the market for disembodied technology acquisition. We would therefore expect Effectiveness of Strategic Protection to primarily affect the firm's EMB decision. 
Drivers for embodied versus disembodied acquisition: in search of exclusion restrictions

If we are able to identify exogenous variables that would affect exclusively the choice of only one of the external sourcing modes, we can further refine our search for the nature of the relationship between embodied and disembodied technology acquisition, i.e. whether it is complementary or substitute, using the exclusion restrictions result as discussed above. Unfortunately, as the discussion so far has shown, the literature offers little guidance for identifying such exclusive variables. As discussed, the nature of the appropriation regime may be one such dimension. In addition, we hypothesize that the use of embodied versus disembodied technology acquisition will depend on technology life cycle and how welldeveloped the market for buying the technology embodied versus disembodied is. A more fluid technology market, with a larger number of active buyers and sellers for technologies that are al ready beyond their early pre-paradigm technology life cycle, will have lower transaction cost. We therefore expect that firms are more likely to use disembodied (embodied) technology acquisition if the market for disembodied (embodied) technology acquisition is more developed. We measure the latter by the use of the external technology sourcing activities in our sample at the industry level, resp. IndDEM B and IndEM B. IndDEM B is expected to have a positive effect on DEM $B$ in the bivariate probit analysis. However, if the same variable IndDEM $B$ shows up in the EMB with a positive (negative) effect, then this is consistent with a complementary (substitute) relationship between EMB and DEMB buy. A similar story holds for IndEMB, which is expected to have a positive effect on $E M B$, while a positive (negative) coefficient in $D E M B$ is reminiscent of a complementary (substitute) relationship between EM B and DEMB.

\section{The econometric results}

Innovative performance results

The results are presented in Table 4. Next to industry dummies, firm size, innovation intensity and export intensity are important variables controlling for firm characteristics in innovation performance across different specifications. The data suggest that small firms (Size) and more intensive innovation spenders are more successful in terms of innovation performance. More export-oriented firms (Export Intensity) are also more innovation productive, presumably because of the more competitive environment they face. Unsurprisingly, perceived lack of technological and market opportunities reduces innovation performance. However, these effects are not significant, probably because they have a greater effect on the likelihood of being innovative in the first place, rather than on the degree of innovativeness. 


\section{Table 4}

Productivity Regressions: dependent variable \% Sales from New Products

\begin{tabular}{|c|c|c|c|}
\hline & $\begin{array}{c}(1) \\
\text { Total Sample }\end{array}$ & $\begin{array}{c}(2) \\
\text { Small }(<250)\end{array}$ & $\begin{array}{c}(3) \\
\text { Large }(>250)\end{array}$ \\
\hline Sales & $\begin{array}{c}-0.022^{* *} \\
(0.011) \\
\end{array}$ & $\begin{array}{l}-0.041^{*} \\
(0.024)\end{array}$ & $\begin{array}{l}-0.0201 \\
(0.019)\end{array}$ \\
\hline Innovation Intensity & $\begin{array}{c}0.465 \\
(0.407)\end{array}$ & $\begin{array}{l}1.051^{\star *} \\
(0.438)\end{array}$ & $\begin{array}{l}-0.067 \\
(0.547) \\
\end{array}$ \\
\hline Export Intensity & $\begin{array}{l}0.001^{* *} \\
(0.0004)\end{array}$ & $\begin{array}{c}0.002^{* * *} \\
(0.001)\end{array}$ & $\begin{array}{c}0.001 \\
(0.001)\end{array}$ \\
\hline Market Obstacles & $\begin{array}{l}-0.032 \\
(0.022)\end{array}$ & $\begin{array}{l}-0.0156 \\
(0.0312)\end{array}$ & $\begin{array}{l}-0.033 \\
(0.029)\end{array}$ \\
\hline Technological Obstacles & $\begin{array}{l}-0.019 \\
(0.014) \\
\end{array}$ & $\begin{array}{l}-0.0280 \\
(0.0221) \\
\end{array}$ & $\begin{array}{l}-0.021 \\
(0.022) \\
\end{array}$ \\
\hline$D E M B \& E M B$ & $\begin{array}{l}0.336^{* * *} \\
(0.092)\end{array}$ & $\begin{array}{l}0.339^{* *} \\
(0.151)\end{array}$ & $\begin{array}{l}0.334^{* *} \\
(0.147)\end{array}$ \\
\hline DEMBOnly & $\begin{array}{l}0.298^{\star \star *} \\
(0.082)\end{array}$ & $\begin{array}{l}0.368^{\star \star *} \\
(0.138)\end{array}$ & $\begin{array}{l}0.280^{\star *} \\
(0.139)\end{array}$ \\
\hline EMBOnly & $\begin{array}{c}0.345^{\star * *} \\
(0.088)\end{array}$ & $\begin{array}{c}0.455^{\star * *} \\
(0.148) \\
\end{array}$ & $\begin{array}{l}0.302^{\star *} \\
(0.133)\end{array}$ \\
\hline NoDEMB\&EMB & $\begin{array}{c}0.243^{* * *} \\
(0.082) \\
\end{array}$ & $\begin{array}{c}0.325^{\star *} \\
(0.14) \\
\end{array}$ & $\begin{array}{c}0.212 \\
(0.145) \\
\end{array}$ \\
\hline Industry Dummies & Included & Included & Included \\
\hline $\begin{array}{l}\text { Complementarity Test: } \\
\text { DEMB\&EMB - DEMBOnly }> \\
\text { EMBOnly - NoDEMB\&EMB } \\
\text { (Significant level for one-sided } \\
\text { test) }\end{array}$ & $\begin{array}{c}F(1,195)=1.51 \\
(0.110)\end{array}$ & $\begin{array}{c}F(1,86)=4.29 \\
(0.021)\end{array}$ & $\begin{array}{c}F(1,89)=0.20 \\
(0.325)\end{array}$ \\
\hline Model & $F(20,215)=13 \cdot 21^{* * *}$ & $F(20,86)=13.65^{\star \star *}$ & $F(20,89)=7.53^{\star * *}$ \\
\hline
\end{tabular}

Turning to the question of complementarity versus substitutability we find that for the full sample the external sourcing activities are substitutes. This effect holds, despite the good performance of the DEM B \&EM B strategy. It is due to the high performance of the exclusive choices, particularly the EMBonly strategy. Interestingly there seems to be an important difference between the behavior of small firms (less than 250 employees, Regression [2]) and large firms (more than 250 employees, Regression [3]). For small firms, embodied and disembodied external knowledge sourcing activities are substitutes, suggesting that small firms are more constrained to combine various external sourcing strategies, or lack the drivers to benefit from any complementarities that combining various strategies might yield. For large firms, the evidence goes more in the direction of complementarity, but the results are not significant.

As we only have information for innovation active firms, the coefficients in the productivity regression may be biased. We use a two-stage Heckman correction procedure to check the results for sample selection bias. ${ }^{8}$ The hypothesis of sample selection is rejected, and the correction does

\footnotetext{
${ }^{8}$ Results are not reported and available upon request. The sample selection is for whether firms are innovation active or not. In the first stage, the innovation equation is estimated. In a probit model, we regress whether the firm innovates on the following independent variables: size, export intensity, a number of variables measuring obstacles to innovation (cost, lack of resources, lack of technological/market information, no technological opportunities, lack of demand) and industry dummies (see Veugelers and Cassiman, 1999, for a development of this result). From the resulting estimation we construct the Heckman correction term $(\lambda)$ to be included in the productivity regression.
} 
not affect our main conclusions. We still confirm the substitutability of embodied and disembodied external sourcing activities for small firms. Furthermore, as we have left-censored observations on innovation performance, we also performed a Tobit regression. ${ }^{9}$ Since we have only a limited number of left censored cases, the main results are not affected.

\section{Multinomial logit results}

Table 5 presents the result of a multinomial logit where we use the external technology sourcing strategies, i.e. the exclusive combinations of DEMB and EMB decisions, as the dependent variable. ${ }^{10}$ As expected, although the overall explanatory power of the model is significant, there are very few expected variables that turn out to significantly affect the exclusive choices. The multinomial logit results are most interesting in pointing out some significant variables affecting the combined choice of DEMB\&EMB acquisition, pointing towards drivers for complementarity. Basic R\&D Reliance although only marginally significant, positively affects the combination of both modes of external technology acquisition, supporting the importance of absorptive capacity generated by this variable as a driver for complementarity in innovation strategies. Also Size and more effective appropriation - legal or strategic - positively affects the combination strategy EMB\&DEMB. Resource Limitations positively affects the combination strategy, possibly indicating that it is precisely firms that combine several external technology sourcing strategies that experience this resource constraint.

\section{Table 5}

Multinomial Logit

\begin{tabular}{|c|c|c|c|}
\hline & DEMBOnly & EMBOnly & DEMB\&EMB \\
\hline Sales & $\begin{array}{r}0.192 \\
(0.157) \\
\end{array}$ & $\begin{array}{c}-0.330^{* *} \\
(0.172)\end{array}$ & $\begin{array}{l}0.355^{\star} \\
(0.163) \\
\end{array}$ \\
\hline $\begin{array}{l}\text { Innovation } \\
\text { Intensity }\end{array}$ & $\begin{array}{l}2.434 \\
(5.587)\end{array}$ & $\begin{array}{c}6.140 \\
(6.100)\end{array}$ & $\begin{array}{c}1.757 \\
(5.213)\end{array}$ \\
\hline $\begin{array}{l}\text { Effectiveness of } \\
\text { IP Protection }\end{array}$ & $\begin{array}{c}0.162 \\
(0.253)\end{array}$ & $\begin{array}{c}1.108 \\
(1.537)\end{array}$ & $\begin{array}{l}2.220^{*} \\
(1.364)\end{array}$ \\
\hline $\begin{array}{l}\text { Effectiveness of } \\
\text { Strategic } \\
\text { Protection }\end{array}$ & $\begin{array}{l}-0.139 \\
(0.268)\end{array}$ & $\begin{array}{l}-0.649^{*} \\
(0.357)\end{array}$ & $\begin{array}{c}1.731^{* * *} \\
(0.445)\end{array}$ \\
\hline $\begin{array}{l}\text { Basic R\&D } \\
\text { Reliance }\end{array}$ & $\begin{array}{c}0.262 \\
(0.805)\end{array}$ & $\begin{array}{c}0.729 \\
(0.989)\end{array}$ & $\begin{array}{l}1.040^{+} \\
(0.725)\end{array}$ \\
\hline $\begin{array}{l}\text { Resource } \\
\text { Limitations }\end{array}$ & $\begin{array}{c}0.307 \\
(0.243)\end{array}$ & $\begin{array}{c}0.378 \\
(0.291)\end{array}$ & $\begin{array}{l}0.537^{* *} \\
(0.273)\end{array}$ \\
\hline $\begin{array}{l}\text { Financial } \\
\text { Limitations }\end{array}$ & $\begin{array}{l}-1.279 \\
(1.061)\end{array}$ & $\begin{array}{c}1.243 \\
(1.474)\end{array}$ & $\begin{array}{l}-1.623 \\
(1.229)\end{array}$ \\
\hline $\begin{array}{l}\text { Competitor } \\
\text { Information }\end{array}$ & $\begin{array}{l}-0.316 \\
(0.205) \\
\end{array}$ & $\begin{array}{l}-0.012 \\
(0.235) \\
\end{array}$ & $\begin{array}{c}0.087 \\
(0.186) \\
\end{array}$ \\
\hline $\begin{array}{l}\text { HighTech } \\
\text { Industry }\end{array}$ & $\begin{array}{c}1.348 \\
(0.694)\end{array}$ & $\begin{array}{l}2.274^{\star \star} \\
(0.885)\end{array}$ & $\begin{array}{c}0.399 \\
(0.690) \\
\end{array}$ \\
\hline IndDEMB & $\begin{array}{l}2.440 \\
(2.175) \\
\end{array}$ & $\begin{array}{l}-6.741 \\
(2.747) \\
\end{array}$ & $\begin{array}{c}3.430 \\
(2.550) \\
\end{array}$ \\
\hline IndEMB & $\begin{array}{l}-0.660 \\
(4.079)\end{array}$ & $\begin{array}{c}7.474 \\
(5.363)\end{array}$ & $\begin{array}{c}10.075 \\
(6.434)^{+}\end{array}$ \\
\hline & \multicolumn{3}{|c|}{$\begin{array}{c}\text { Pseudo } R^{2}=0.164 \\
\chi^{2}(33)=77.90^{\star * \star} \\
N=202\end{array}$} \\
\hline \multicolumn{4}{|c|}{$\begin{array}{c}\text { Coefficients significant at: } 1 \% \%^{* * *}, 5 \% \%^{* *}, 10 \%^{*} \text { and } 15 \%^{+} \text {. Standard } \\
\text { deviations in brackets. }\end{array}$} \\
\hline
\end{tabular}

\footnotetext{
${ }^{9}$ Innovation performance is measured as a percentage of sales. 24 firms reported $0 \%$ of sales from new or substantially improved products introduced between 1990 and 1992. Results available from the authors upon request. ${ }^{10}$ The benchmark case is NoEM B \&DEMB.
} 
Bivariate probit results

Through an exclusion restriction, a stronger test of the nature of the relation between external innovation activities can be performed. However, this requires finding a reasonable excluded variable in one of the adoption equations of DEMB or EMB in the bivariate probit. We hypothesized that if the market for disembodied (embodied) technology acquisition is better developed, the firm is more likely to be engaged in disembodied (embodied) buy. Our results from the multinomial logit regression were al ready consistent with such an exclusion restriction. In the bivariate probit results, IndEMB significantly increases the likelihood of the firm's choice of $E M B$, and this holds for both small and large firms. But more interestingly, IndEMB shows up significantly negative in the small firm's choice to acquire technology DEMB, consistent with a substitute relationship between EMB and DEMB for small firms, as already found in the productivity analysis. For large firms, IndEMB significantly increases the probability of the firm buying technology disembodied, supporting a complementary relationship between EMB and DEM B for large firms, as was also suggested, but not found to be significant, in the productivity analysis. A similar but weaker result holds for the effect of IndDEM B. The industry variable again significantly drives the firm's choice for DEMB acquisition, both for large and small firms. In addition, it affects the firm's choice to acquire embodied technology, negatively for small firms, and positively for large firms. This is again consistent with a substitute relationship for small firms, while large firms enjoy a complementary relationship, but these cross-effects fail to show up significantly. Also, the different modes of appropriation describe a similar exclusion story. Strategic protection significantly affects the EMB decision of small innovating firms and, consistent with substitution, also indirectly negatively affects the small firms' disembodied technology acquisition, but these effects are only marginally significant. Also, the results on legal protection are suggestive of a substitute relationship for small firms, but again the results are not significant. 
Table 6

Bivariate Probit

\begin{tabular}{|c|c|c|c|c|c|c|}
\hline & \multicolumn{2}{|c|}{ Total Sample } & \multicolumn{2}{|c|}{ Small $(<250)$} & \multicolumn{2}{|c|}{ Large $(>250)$} \\
\hline & EMB & DEMB & EMB & DEMB & EMB & DEMB \\
\hline Sales & $\begin{array}{c}0.012 \\
(0.064)\end{array}$ & $\begin{array}{c}0.202^{* * *} \\
(.072)\end{array}$ & $\begin{array}{l}0.110 \\
(.141)\end{array}$ & $\begin{array}{l}0.197 \\
(.149)\end{array}$ & $\begin{array}{l}0.097 \\
(.167)\end{array}$ & $\begin{array}{l}0.224 \\
(.177)\end{array}$ \\
\hline $\begin{array}{l}\text { Innovation } \\
\text { Intensity }\end{array}$ & $\begin{array}{c}1.321 \\
(2.245) \\
\end{array}$ & $\begin{array}{c}-0.994 \\
(1.803) \\
\end{array}$ & $\begin{array}{c}4.990 \\
(3.530)\end{array}$ & $\begin{array}{l}-2.405 \\
(4.242) \\
\end{array}$ & $\begin{array}{c}0.573 \\
(2.759) \\
\end{array}$ & $\begin{array}{l}-1.118 \\
(2.107) \\
\end{array}$ \\
\hline $\begin{array}{l}\text { Effectiveness } \\
\text { of IP } \\
\text { Protection }\end{array}$ & $\begin{array}{l}-0.090 \\
(0.104)\end{array}$ & $\begin{array}{l}0.236^{\star} \\
(0.120)\end{array}$ & $\begin{array}{l}-0.182 \\
(.157)\end{array}$ & $\begin{array}{c}0.373^{\star *} \\
(.184)\end{array}$ & $\begin{array}{l}-0.121 \\
(.155)\end{array}$ & $\begin{array}{l}0.148 \\
(.179)\end{array}$ \\
\hline $\begin{array}{l}\text { Effectiveness } \\
\text { of Strategic } \\
\text { Protection }\end{array}$ & $\begin{array}{l}0.240^{*} \\
(.127)\end{array}$ & $\begin{array}{l}-0.154 \\
(.126)\end{array}$ & $\begin{array}{l}0.261 \\
(.167)\end{array}$ & $\begin{array}{l}-0.243 \\
(.171)\end{array}$ & $\begin{array}{l}0.261 \\
(.220)\end{array}$ & $\begin{array}{l}-0.313 \\
(.223)\end{array}$ \\
\hline $\begin{array}{l}\text { Basic R\&D } \\
\text { Reliance }\end{array}$ & $\begin{array}{l}0.477 \\
(.343)\end{array}$ & $\begin{array}{l}0.252 \\
(.364)\end{array}$ & $\begin{array}{l}0.631 \\
(.490)\end{array}$ & $\begin{array}{l}-0.080 \\
(.505)\end{array}$ & $\begin{array}{l}0.461 \\
(.525)\end{array}$ & $\begin{array}{l}0.540 \\
(.532)\end{array}$ \\
\hline $\begin{array}{l}\text { Resource } \\
\text { Limitations }\end{array}$ & $\begin{array}{l}0.191^{*} \\
(.105)\end{array}$ & $\begin{array}{l}0.152 \\
(.106)\end{array}$ & $\begin{array}{l}0.247^{\star} \\
(.138)\end{array}$ & $\begin{array}{l}0.054 \\
(.143)\end{array}$ & $\begin{array}{l}0.151 \\
(.174)\end{array}$ & $\begin{array}{l}0.220 \\
(.165)\end{array}$ \\
\hline $\begin{array}{l}\text { Financial } \\
\text { Limitations }\end{array}$ & $\begin{array}{l}0.124 \\
(.521)\end{array}$ & $\begin{array}{c}-1.087^{*} \\
(.553)\end{array}$ & $\begin{array}{l}-0.996 \\
(.780)\end{array}$ & $\begin{array}{l}-0.662 \\
(.815)\end{array}$ & $\begin{array}{l}0.879 \\
(.791)\end{array}$ & $\begin{array}{r}-1.612^{*} \\
(.883)\end{array}$ \\
\hline $\begin{array}{l}\text { Competitor } \\
\text { Information }\end{array}$ & $\begin{array}{l}0.107 \\
(.088)\end{array}$ & $\begin{array}{r}-0.044 \\
(.094)\end{array}$ & $\begin{array}{l}-0.071 \\
(.127)\end{array}$ & $\begin{array}{l}-0.074 \\
(.136)\end{array}$ & $\begin{array}{l}0.243^{*} \\
(.139)\end{array}$ & $\begin{array}{l}-0.017 \\
(.140)\end{array}$ \\
\hline $\begin{array}{l}\text { HighTech } \\
\text { Industry }\end{array}$ & $\begin{array}{l}0.017 \\
(.292)\end{array}$ & $\begin{array}{l}0.133 \\
(.314)\end{array}$ & $\begin{array}{l}-0.143 \\
(.473)\end{array}$ & $\begin{array}{l}-0.481 \\
(.484)\end{array}$ & $\begin{array}{l}-0.005 \\
(.391)\end{array}$ & $\begin{array}{l}0.528 \\
(.401)\end{array}$ \\
\hline IndDEMB & $\begin{array}{c}-0.943 \\
(1.003)\end{array}$ & $\begin{array}{c}2.903^{* \star *} \\
(1.105)\end{array}$ & $\begin{array}{c}0.006 \\
(1.456)\end{array}$ & $\begin{array}{c}6.813^{\star \star *} \\
(1.675)\end{array}$ & $\begin{array}{l}-1.649 \\
(1.508)\end{array}$ & $\begin{array}{c}-0.098 \\
(1.572)\end{array}$ \\
\hline \multirow[t]{2}{*}{ IndEMB } & $\begin{array}{l}5.558^{\star *} \\
(2.310)\end{array}$ & $\begin{array}{c}1.016 \\
(2.209)\end{array}$ & $\begin{array}{l}4.686^{\star} \\
(2.972)\end{array}$ & $\begin{array}{l}-4.833^{*} \\
(2.994)\end{array}$ & $\begin{array}{l}7.218^{*} \\
(3.913)\end{array}$ & $\begin{array}{l}7.515^{\star} \\
(3.661)\end{array}$ \\
\hline & \multicolumn{2}{|c|}{$\begin{array}{c}\text { Correlation } 0.213 \\
(.116) \\
\begin{array}{c}\chi^{2}(1)=3.185^{\star} \\
N=202\end{array}\end{array}$} & \multicolumn{2}{|c|}{$\begin{array}{c}\text { Correlation } 0.030 \\
(.183) \\
\begin{array}{c}\chi^{2}(1)=0.026 \\
N=97\end{array}\end{array}$} & \multicolumn{2}{|c|}{$\begin{array}{c}\text { Correlation } 0.433 \\
(.158) \\
\begin{array}{c}\chi^{2}(1)=5.67^{\star *} \\
N=105 \\
\end{array}\end{array}$} \\
\hline
\end{tabular}

Coefficients significant at: $1 \%{ }^{* \star *}, 5 \%{ }^{* \star}$ and $10 \%{ }^{*}$. Standard deviations in brackets. 


\section{Conclusions}

In this study, we take a closer look at the relationship between various external technology acquisition strategies. We distinguish two broad types of technology sourcing decisions of the firm. On the one hand, the firm can acquire new technology which is embodied in new personnel that is attracted to it. On the other hand, the firm can obtain new technology disembodied through a licensing agreement or by R\&D contracting. Using the methodology developed in Cassiman and Veugelers (2006), we systematically examine the substitute versus complementary relationship between these two different types of external technology sourcing. Going beyond the mere identification of the relationship, the analysis also focuses on the contextual variables affecting this perceived relationship. We use both an innovation productivity as well as an adoption approach to test for the nature and the drivers of the relationship between the two acquisition modes.

We test the methodology for a set of innovative companies across all manufacturing sectors, drawn from the Community Innovation Survey for Belgium. From the innovative productivity analysis, we find that external sourcing, irrespective of the mode, increases innovative performance. With respect to the choice between the different external sourcing modes, we find that the choice of external sourcing between embodied or disembodied modes is substitutive for smaller firms. Smaller firms in particular obtain higher performance from selecting an embodied technology acquisition strategy only. Larger firms tend to combine different external technology acquisition strategies, but complementarity effects are not significant in our sample. Results from the adoption approach confirm the substitute (complement) nature of the relationship for small (large) firms, but they also reveal the contextual variables affecting complementarity. We find basic R\&D Reliance and firm size as components of a firm's absorptive capacity to significantly affect the likelihood of a combined sourcing choice. Also, the nature of the appropriation regime and the technology used, particularly how transferable the technology is on the market, affects the choice between the various combinations of external sourcing activities.

Given the lack of previous empirical work on this topic, particularly the lack of a rigorous empirical framework for testing complementarity/substitutability, the first results on our small Belgian sample, although not strongly significant, nevertheless provide some interesting suggestions for further research. More empirical work using the same methodology needs to be done to check the results' robustness on larger samples. The EUROSTAT/CIS data proves to be a rich set of information, allowing replication of this exercise in other European countries. However, the qualitative nature of most of the information limits the analysis, in terms of quantifying innovation strategies. But perhaps even more important is the need for more theoretical work to help distinguish the drivers for different external technology sourcing modes. 


\section{References}

Acs, Z. and D. Audretsch (1987), "Innovation, market structure and firm size," The Review of Economics and Statistics, 71, pp. 567-574.

Allen, T. (1977), "Managing the flow of technology," MIT Press, Cambridge, MA, 256 pp.

Arora, A. (1996), "Testing for Complementarities in Reduced-Form Regressions: A Note," Economic Letters, 50, pp. 51-55.

Arora, A. and A. Gambardella (1990), "Complementarity and external linkages: the strategies of the large firms in biotechnology," J ournal of Industrial Economics, 38, pp. 361-379.

Arora, A. and A. Gambardella (1994), "Evaluating technological information and utilizing it," J ournal of Economic Behavior and Organization, 24, pp. 91-114.

Arrow, K. (1962), "Economic welfare and the allocation of resources for innovation," in R. Nelson (Ed.), "The rate and direction of inventive activity," pp. 609-626. (Princeton, NJ : Princeton University Press).

Athey, S. and S. Stern (1998), "An Empirical Framework for Testing Theories about Complementarity in Organizational Design," NBER working paper \#6600.

Belderbos, R., M. Carree, and B. Lokshin (2004), "Cooperative R\&D and firm performance," Research Policy 33 (10), pp. 1477-1492.

Cassiman, B. and R. Veugelers (2006), "In Search of Complementarity in Innovation Strategy: Internal R\&D, Cooperation in R\&D and External Technology Acquisition," Management Science, 52, 1, pp. 68-82.

Chatterji, D. (1996), "Accessing external sources of technology," Research and Technology Management, 39, pp. 48-56.

Cockburn, I. and R. Henderson (1998), "Absorptive capacity, coauthoring behavior and the organization of research in drug discovery," Journal of Industrial Economics, 46, pp. 157-182.

Cohen, W. and D. Levinthal (1989), "Innovation and Learning: the two faces of R\&D," The Economic J ournal, 99, pp. 569-596.

Cohen, W. and R. Levin (1989), "Empirical studies of innovation and market structure," in Schmalensee, R. and R. Willig (Eds.), "Handbook of industrial organisation," pp. 1060-1107 (North-Holland).

Crépon, B., E. Duguet, and J. Mairesse (1998), "Research, Innovation and Productivity: An Econometric Analysis at the Firm Level," Economics of Innovation and New Technology, 7 (2), pp. 115- 158.

De Bondt, R. (1997), "Spillovers and innovative activities," International J ournal of Industrial Organization, 15, pp. 1-28.

Gambardella, A. (1992), "Competitive Advantages from In-house Basic Research," Research Policy, Vol. 21, pp. 391-407.

Gersbach, H. and A. Schmutzler (2003), "Endogenous Technological Spillovers: Causes and Consequences," J ournal of Economics \& M anagement Strategy, 12, pp. 179-205.

Granstrand, O., E. Bohlin, C. Oskarsson, and N. Sjöberg (1992), "External Technology Acquisition in Large Multitechnology Corporations," R\&D Management, 22, pp. 111-133. 
Grossman, S. and O. Hart (1986), "The costs and benefits of ownership: a theory of vertical and lateral integration," J ournal of Political Economy, 94, pp. 691-719.

Milgrom, P. and J. Roberts (1990), "The Economics of Modern Manufacturing: Technology, Strategy, and Organization," A merican Economic Review, 80, pp. 511-528.

Milgrom, P. and J. Roberts (1995), "Complementarities and Fit: Strategy, Structure and Organizational Change in Manufacturing," Journal of Accounting and Economics, 19, pp. 179-208.

Mowery, D. and N. Rosenberg (1989), "Technology and the Pursuit of Economic Growth," Cambridge University Press, $338 \mathrm{pp}$.

Roberts, E. and C. Berry (1985), "Entering new businesses: selecting strategies for success," Sloan Management Review, 26, pp. 3-17.

Pavitt (1984), "Sectoral patterns of technical change: Towards a taxonomy and a theory," Research Policy, 13, pp. 343-373.

Rothwell, R. and M. Dodgson (1991), "Technology strategies in small firms," J ournal of General Management, 17, pp. 45-56.

Teece, D. (1986), "Profiting from technological innovation: implications for integration, collaboration, licensing and public policy," Research Policy, 15, pp. 285-305.

Veugelers, R. and B. Cassiman (1999), "Make and Buy in Innovation Strategies: Evidence from Belgian Manufacturing Firms," Research Policy, 28, pp. 63-80.

Williamson, 0. (1985), "The economic institutions of capitalism, firms, markets, relational contracting," (The Free Press, New York). 